\title{
Effect of liming on basic exchangeable cations of soil
}

\author{
Armi Kaila \\ University of Helsinki, Department of Agricultural Chemistry
}

\begin{abstract}
The effect of liming on the basic exchangeable cations in a sand, a heavy clay and a muddy clay soil was studied with a 9 month's incubation experiment under laboratory conditions. Besides, observations were made in connection with some other incubation and field experiments.

It was found that application of $\mathrm{CaCO}_{3}$ in amounts which reduced the acidity to about $\mathrm{pH} \mathrm{7}$, decreased the content of exchangeable $\mathrm{Mg}$ in all experiments, and even a lower application effectively prevented any net release of nonexchangeable $\mathrm{Mg}$ which occurred in the muddy clay samples incubated without lime. Some fixation of $\mathrm{K}$ was also usually detected, but liming increased the amount of exchangeable Na.

Essential differences apparently exist between the mechanisms of the retention of $\mathrm{Mg}$ and $\mathrm{K}$ induced by liming: Significantly lower amounts of $\mathrm{Mg}$ was extracted by 0.5 $\mathrm{HCl}$ from the limed samples of the heavy clay and muddy clay soil than from the original ones, while the contrary was true with $\mathrm{K}$.

The mechanisms connected with the $\mathrm{Mg}$ fixation were discussed. Attention was paid to the possibility that the usually poor $\mathrm{Mg}$ supporting ability of Finnish muddy clay soils may be partly connected with the heavy liming necessary for the cultivation of these acid soils.
\end{abstract}

The decrease in soil acidity as a result of liming is likely to increase the effective cation exchange capacity of the soil and also to exert some effect on the exchangeability of the basic cations. Fixation of some cations in nonexchangeable forms may occur, but also release of cations from organic matter or minerals is possible, particularly, during prolonged periods. In the field, losses of cations by leaching or uptake of cations by plant roots will complicate the processes.

In the present paper the effect of application of calcium carbonate on the basic exchangeable cations of three mineral soils is studied on the basis of an incubation experiment under laboratory conditions. Besides, results of some laboratory and field experiments are examined from this point of view.

\section{Experimental}

Samples of a sand soil, a heavy clay soil and a muddy clay or gyttja clay soil were collected from virgin land of the university farm in Helsinki. The 
samples were air-dried and ground to pass $2 \mathrm{~mm}$ sieve. $5 \mathrm{~kg}$ samples of the sand and heavy clay soils and $4 \mathrm{~kg}$ samples of the muddy clay soil were incubated in Mitscherlich pots at about field capacity and at room temperature $\left(19-24^{\circ} \mathrm{C}\right)$ for nine months. All three soils were incubated without any application and with $\mathrm{CaCO}_{3}$ corresponding to $7.5 \mathrm{me} / 100 \mathrm{~g}$ of dry soil. To the muddy clay, $\mathrm{CaCO}_{3}$ was also added in amounts of $15,22.5,30$, or $60 \mathrm{me} / 100 \mathrm{~g}$. All treatments were in triplicates. At the end of the experimental period the samples were air-dried and passed through a $2 \mathrm{~mm}$ sieve.

The exchangeable cations were extracted by washing $5 \mathrm{~g}$ of soil with four $50 \mathrm{ml}$-portions of several buffered or unbuffered one normal salt solutions: $\mathrm{NH}_{4} \mathrm{OAc}$ at $\mathrm{pH} 7,0.9 \mathrm{~N} \mathrm{CaOAc}+0.1 \mathrm{~N} \mathrm{CaCl}_{2}$ at $\mathrm{pH} 7, \mathrm{NH}_{4} \mathrm{Cl}, \mathrm{KCl}$ and $\mathrm{CaCl}_{2}$. Acid-soluble $\mathrm{Ca}, \mathrm{Mg}, \mathrm{K}$, and $\mathrm{Na}$ were extracted with $0.5 \mathrm{~N} \mathrm{HCl}$ by shaking for one hour in the ratio of 1 part of soil to 20 parts of the solution. Ca and $\mathrm{Mg}$ in the extracts were measured by a Perkin Elmer atomic absorption spectrophotometer 290, $\mathrm{K}$ and $\mathrm{Na}$ by an EEL-flame photometer.

Table 1. Soil samples

\begin{tabular}{|c|c|c|c|}
\hline & Sand & Heavy clay & Muddy clay \\
\hline Sampling depth $\mathrm{cm}$........................... & $0-30$ & $0-40$ & $0-100$ \\
\hline 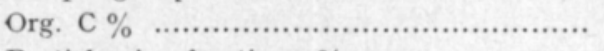 & 2.89 & 0.67 & 2.94 \\
\hline \multicolumn{4}{|l|}{ Particle size fractions $\%$} \\
\hline$<2 \mu \mathrm{m} \ldots \ldots \ldots \ldots \ldots \ldots \ldots \ldots \ldots \ldots \ldots \ldots$ & 14 & 78 & 59 \\
\hline $2-20 \mu \mathrm{m} \quad \ldots \ldots \ldots \ldots \ldots \ldots \ldots \ldots \ldots \ldots \ldots \ldots \ldots \ldots$ & 6 & 14 & 28 \\
\hline $20-200 \mu \mathrm{m}$ & 24 & 7 & 11 \\
\hline $200-2000 \mu \mathrm{m} \quad \ldots \ldots \ldots \ldots \ldots \ldots \ldots \ldots \ldots \ldots \ldots \ldots \ldots \ldots$ & 56 & 1 & 2 \\
\hline 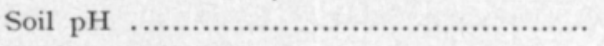 & 6.0 & 5.7 & 3.5 \\
\hline \multicolumn{4}{|l|}{ Acidity me $/ 100 \mathrm{~g}$} \\
\hline $\mathrm{N} \mathrm{KCl} \ldots \ldots \ldots \ldots \ldots \ldots$ & 0.2 & 0.4 & 11.0 \\
\hline $\mathrm{N} \mathrm{NH}_{4} \mathrm{OAc}$ at $\mathrm{pH} \quad 7 \ldots \ldots \ldots \ldots \ldots \ldots \ldots \ldots$ & 5.8 & 8.5 & 27.5 \\
\hline
\end{tabular}

The results were treated by Duncan's new multiple range test. (Duncan 1955).

The soils are characterized by data in Table 1. Soil $\mathrm{pH}$ was measured in a $0.01 \mathrm{M} \mathrm{CaCl}_{2}$ suspension in the ratio of 1 to 2.5 . Soil acidity was titrated in connection with the determination of the exchangeable cations with $\mathrm{N} \mathrm{KCl}$ and $\mathrm{N} \mathrm{NH}_{4} \mathrm{OAc}$ at $\mathrm{pH} 7$.

The heavy clay sample is poor in organic $\mathrm{C}$ because of the high sampling depth. The muddy clay sample, on the other hand, has its typical high content of organic matter even down to the depth of one meter. The sand soil is exceptionally rich in the clay fraction as is also the case with the muddy clay soil. The very low $\mathrm{pH}$-value of the muddy clay sample is in accordance with its high exchange acidity which exceeds the lowest amount of $\mathrm{CaCO}_{3}$ applied. The exchange acidity is very low in the sand and heavy clay soils. The titratable acidity at $\mathrm{pH} 7$ is in the former soil lower and in the latter soil only slightly higher than the amount of lime applied in the experiment. 
The basic exchangeable cations replaced by unbuffered $\mathrm{N} \mathrm{NH}_{4} \mathrm{Cl}$ are recorded in Table 2. The figures for $\mathrm{Ca}$ in the limed samples are in parenthesis, since it is likely that, at least at the higher $\mathrm{pH}$-values, $\mathrm{CaCO}_{3}$ had not completely reacted with the soil, and a part of it may only have been dissolved by $\mathrm{NH}_{4} \mathrm{Cl}$.

In the limed samples of sand and heavy clay soils $\mathrm{pH}$ is 6.9 , but in the muddy clay soil only an eightfold amount of $\mathrm{CaCO}_{3}$ was enough to keep the reaction at about neutrality. The $\mathrm{pH}$-values in this soil measured after one week of incubation were $\mathrm{pH} 3.5,4.1,4.7,5.6,6.9$, and 7.2 for the treatments with 0 , $7.5,15,22.5,30$, and $60 \mathrm{me} / 100 \mathrm{~g}$, respectively. In the following weeks the acidity increased rapidly in samples limed with 7.5 to $22.5 \mathrm{me} / 100 \mathrm{~g}$, but 30 $\mathrm{me} / 100 \mathrm{~g}$ was able to keep the $\mathrm{pH}$ of the muddy clay for four weeks higher than $\mathrm{pH} 6$ and for 13 weeks higher than $\mathrm{pH} 5$.

In all soils incubation with lime which kept the soil $\mathrm{pH}$ at about 7 distinctly decreased the amount of $\mathrm{Mg}$ replaced by washing with $\mathrm{N} \mathrm{NH}_{4} \mathrm{Cl}$. In the sand and heavy clay soils, this decrease was about $30 \%$, in the muddy clay soil only slightly lower than $50 \%$ of the content of exchangeable $\mathrm{Mg}$ in the original sample. In the highly acid muddy clay soil incubated without lime or with 7,5 me/100 g, some release of nonexchanheable $\mathrm{Mg}$ is apparent. This net release was completely prevented by $15 \mathrm{me} / 100 \mathrm{~g}$, and a statistically significant decrease in the content of exchangeable $\mathrm{Mg}$ is detectable in sample incubated with $30 \mathrm{me} / 100 \mathrm{~g}$, which was enough to keep the soil only slightly acid for several weeks.

Table 2. Basic exchangeable cations in soil samples replaced by $\mathrm{N} \mathrm{NH}_{4} \mathrm{Cl}(\mathrm{me} / 100 \mathrm{~g}$ )

\begin{tabular}{ccccccc}
\hline & $\begin{array}{c}\mathrm{CaCO}_{3} \\
\mathrm{me} / 100 \mathrm{~g}\end{array}$ & $\begin{array}{l}\text { Soil } \\
\mathrm{pH}^{*}\end{array}$ & $\mathrm{Ca}^{*}$ & $\mathrm{Mg}^{*}$ & $\mathrm{~K}^{*}$ & $\mathrm{Na}^{*}$ \\
\hline Sand & & & & & & \\
Original & & $6.0^{\mathrm{b}}$ & $10.1^{\mathrm{a}}$ & $0.47^{\mathrm{b}}$ & $0.35^{\mathrm{b}}$ & $0.18^{\mathrm{a}}$ \\
Incubated & 0 & $5.8^{\mathrm{a}}$ & $10.0^{\mathrm{a}}$ & $0.49^{\mathrm{b}}$ & $0.33^{\mathrm{ab}}$ & $0.18^{\mathrm{a}}$ \\
& 7.5 & $6.9^{\mathrm{c}}$ & $(15.8)$ & $0.32^{\mathrm{a}}$ & $0.30^{\mathrm{a}}$ & $0.26^{\mathrm{b}}$ \\
Heavy clay & & & & & & \\
Original & & $5.7^{\mathrm{b}}$ & $10.1^{\mathrm{a}}$ & $8.2^{\mathrm{b}}$ & $0.79^{\mathrm{a}}$ & $0.44^{\mathrm{a}}$ \\
Incubated & 0 & $5.6^{\mathrm{a}}$ & $10.3^{\mathrm{a}}$ & $8.2^{\mathrm{b}}$ & $0.85^{\mathrm{b}}$ & $0.47^{\mathrm{b}}$ \\
& 7.5 & $6.9^{\mathrm{c}}$ & $(17.0)$ & $6.0^{\mathrm{a}}$ & $0.78^{\mathrm{a}}$ & $0.55^{\mathrm{c}}$ \\
Muddy clay & & & & & & \\
Original & & $3.6^{\mathrm{b}}$ & $4.9^{\mathrm{a}}$ & $3.6^{\mathrm{c}}$ & $0.92^{\mathrm{d}}$ & $0.85^{\mathrm{a}}$ \\
Incubated & 0 & $3.5^{\mathrm{a}}$ & $4.2^{\mathrm{a}}$ & $4.4^{\mathrm{e}}$ & $0.37^{\mathrm{a}}$ & $0.85^{\mathrm{a}}$ \\
& 7.5 & $3.6^{\mathrm{b}}$ & $(12.9)$ & $4.0^{\mathrm{d}}$ & $0.92^{\mathrm{d}}$ & $1.01^{\mathrm{b}}$ \\
& 15 & $3.8^{\mathrm{c}}$ & $(21.0)$ & $3.6^{\mathrm{c}}$ & $1.09^{\mathrm{e}}$ & $1.04^{\mathrm{b}}$ \\
& 22.5 & $4.3^{\mathrm{d}}$ & $(25.5)$ & $3.4^{\mathrm{bc}}$ & $0.98^{\mathrm{d}}$ & $1.14^{\mathrm{c}}$ \\
& 30 & $4.9^{\mathrm{e}}$ & $(34.4)$ & $3.2^{\mathrm{b}}$ & $0.82^{\mathrm{c}}$ & $1.16^{\mathrm{c}}$ \\
& 60 & $7.1^{\mathrm{f}}$ & $(57.1)$ & $1.9^{\mathrm{a}}$ & $0.62^{\mathrm{b}}$ & $1.44^{\mathrm{d}}$ \\
\hline
\end{tabular}

* Means in each column of the respective soils do not differ at $\mathrm{P}=0.01$ when they are followed by a common letter. 
In the sand and heavy clay soils, liming at least prevented any release of nonexchangeable $K$. In the muddy clay soil, the highest amount of lime brought about a relatively high net fixation of $\mathrm{K}$ : one third of the exchangeable $\mathrm{K}$ in the original sample seems to be fixed. Some decrease in the exchangeable $\mathrm{K}$ is obvious also in the muddy clay soil incubated with 30 me $\mathrm{CaCO}_{3}$.

Incubation without lime slightly increased the amount of exchangeable $\mathrm{K}$ in the heavy clay soil, no statistically significant effect can be found in the low values of the sand soil, but in the muddy clay soil a very marked decrease in the exchangeable $\mathrm{K}$ occurred. This somewhat surprising result which may be partly connected with the accumulation of $\mathrm{NH}_{4}{ }^{+}$-ions in this soil, will be studied more thoroughly in an other work.

In all soils, the amount of exchangeable $\mathrm{Na}$ is increased by liming, but not at all, or only slightly, by the somewhat higher acidity produced during incubation without lime.

Washing with the other buffered or unbuffered solutions gave results which, in respect of the basic exchangeable cations which could be determined, did not markedly differ from those obtained by $\mathrm{N} \mathrm{NH}_{4} \mathrm{Cl}$. At least, the mutual sequence of the respective cations in the differently treated samples was equal. In all soils, incubation with lime decreased the amount of exchangeable $\mathrm{Mg}$ and increased that of $\mathrm{Na}$, while the effect on exchangeable $\mathrm{K}$ was more complicated but similar to that reported in Table 2 . Therefore, these data are not separately recorded in this connection.

Extraction with $0.5 \mathrm{~N} \mathrm{HCl}$ was employed in order to get some more information about the effect of liming on the release or fixation of $\mathrm{Mg}, \mathrm{K}$, and $\mathrm{Na}$. Results in Table 3 indicate that these acid soluble quantities are higher than the corresponding amounts of exchangeable form, though those of $\mathrm{Na}$ in sand and muddy clay soils are not much higher. $\mathrm{CaCO}_{3}$ applied is fairly well recovered by this extraction.

Acid soluble $\mathrm{Mg}$ is in the samples incubated with lime significantly lower than in the unlimed samples. In the heavy clay and muddy clay soils, differences in the acid soluble $\mathrm{Mg}$ between the original samples and the variously treated incubated samples are mainly of the same size as the corresponding differences in the exchangeable $\mathrm{Mg}$. This may be taken to indicate that fixation of $\mathrm{Mg}$ induced by application of $\mathrm{CaCO}_{3}$, to a large part occurred as compounds or complexes which are not readily dissolved by acid.

On the other hand, $\mathrm{K}$ retained unexchangeable in the samples limed to a high $\mathrm{pH}$-value seems to be quite readily soluble in $0.5 \mathrm{~N} \mathrm{HCl}$, or at least $\mathrm{K}$ in the limed samples is more easily soluble than $\mathrm{K}$ in the unlimed samples of the both clay soils. In the muddy clay soil this is particularly marked, since $\mathrm{K}$ fixed in the sample incubated without lime seems to be bound in acid-insoluble forms. Apparently, there are different mechanisms not only between the lime induced fixation of $\mathrm{Mg}$ and $\mathrm{K}$, but also between the retention of $\mathrm{K}$ in unexchangeable position in the limed and unlimed samples of the muddy clay soil.

The positive effect of liming on the acid soluble $\mathrm{Na}$ is equal to its effect on the exchangeable $\mathrm{Na}$ in the sand and muddy clay soil. In the heavy clay soil, the tendency towards the same direction is not statistically significant. 


\begin{tabular}{|c|c|c|c|c|c|}
\hline & $\begin{array}{c}\mathrm{CaCO}_{3} \\
\mathrm{me} / 100 \mathrm{~g}\end{array}$ & $\mathrm{Ca}^{*}$ & $\mathrm{Mg}^{*}$ & $\mathrm{~K}^{*}$ & $\mathrm{Na}^{*}$ \\
\hline \multicolumn{6}{|l|}{ Sand } \\
\hline Original .................... & & $14.0^{\mathrm{a}}$ & $0.93^{\mathrm{a}}$ & $0.55^{\mathrm{a}}$ & $0.22^{\mathrm{a}}$ \\
\hline \multirow{2}{*}{ Incubated ................ } & 0 & $14.5^{\mathrm{a}}$ & $1.00^{\mathrm{b}}$ & $0.55^{\mathrm{a}}$ & $0.21^{\mathrm{a}}$ \\
\hline & 7.5 & $21.8^{\mathrm{b}}$ & $0.90^{\mathrm{a}}$ & $0.55^{\mathrm{a}}$ & $0.27^{\mathrm{b}}$ \\
\hline \multicolumn{6}{|l|}{ Heavy clay } \\
\hline Original ................... & & $13.9^{\mathrm{a}}$ & $18.0^{\mathrm{b}}$ & $1.86^{\mathrm{a}}$ & $0.75^{\mathrm{a}}$ \\
\hline \multirow[t]{2}{*}{ Incubated ................. } & 0 & $13.2^{\mathrm{a}}$ & $18.3^{b}$ & $2.33^{\mathrm{b}}$ & $0.85^{b}$ \\
\hline & 7.5 & $20.8^{b}$ & $16.8^{\mathrm{a}}$ & $2.54^{\mathrm{c}}$ & $0.89^{b}$ \\
\hline \multicolumn{6}{|l|}{ Muddy clay } \\
\hline Original ..................... & & $6.9^{\mathrm{a}}$ & $7.0^{\mathrm{c}}$ & $1.34^{\mathrm{c}}$ & $0.95^{\mathrm{a}}$ \\
\hline \multirow[t]{5}{*}{ Incubated ................. } & 0 & $6.3^{\mathrm{a}}$ & $6.9^{d}$ & $0.71^{\mathrm{a}}$ & $0.95^{\mathrm{a}}$ \\
\hline & 7.5 & $14.3^{\mathrm{b}}$ & $6.3^{c}$ & $1.26^{\mathrm{b}}$ & $1.06^{\mathrm{b}}$ \\
\hline & 15 & $22.3^{\mathrm{c}}$ & $5.5^{\mathrm{b}}$ & $1.42^{\mathrm{d}}$ & $1.13^{\mathrm{c}}$ \\
\hline & 30 & $37.1^{\mathrm{b}}$ & $5.4^{\mathrm{b}}$ & $1.58^{e}$ & $1.25^{\mathrm{d}}$ \\
\hline & 60 & $66.6^{e}$ & $5.0^{\mathrm{a}}$ & $1.58^{\mathrm{e}}$ & $1.62^{\mathrm{e}}$ \\
\hline
\end{tabular}

* Means in each column of the respective soils do not differ at $\mathrm{P}=0.01$ when they are followed by a common letter.

\section{Other observations}

Results obtained in connection of some other incubation and field experiments largely corroborated that heavy liming of an acid soil is likely to decrease the amount of exchangeable $\mathrm{Mg}$ and often also to some extent that of exchangeable $\mathrm{K}$, while the content of exchangeable $\mathrm{Na}$ tends to increase with liming.

In a field trial on a clay loam soil of $\mathrm{pH} 5.4$, liming in the spring with 14000 $\mathrm{kg} \mathrm{CaCO}$ per hectar, until autumn decreased the acidity to $\mathrm{pH}$ 6.8. In samples collected in autumn or after 3 months from the fallow plots, the content of exchangeable $\mathrm{Mg}$ in the unlimed samples was $0.89 \mathrm{me} / 100 \mathrm{~g}$, in the limed ones $0.57 \mathrm{me} / 100 \mathrm{~g}$. The corresponding figures for exchangeable $\mathrm{K}$ were 0.23 and $0.18 \mathrm{me} / 100 \mathrm{~g}$, respectively, and those for exchangeable $\mathrm{Na} 0.20$ and $0.33 \mathrm{me} /$ $100 \mathrm{~g}$. The respective differences were statistically highly significant.

In an incubation experiment under laboratory conditions with three acid muddy clay soils sampled both from the surface layer and from the depth of 40 to $60 \mathrm{~cm}$, incubation for 6 months with $0,0.5,1.0$, and $2.0 \% \mathrm{CaCO}_{3}$ resulted in average $\mathrm{pH}$-values of $3.9,5.1,5.9$, and 6.8 , respectively. The content of exchangeable $\mathrm{Mg}$ was at the lowest rate of liming about $85 \%$, at the second rate about $70 \%$, and at the highest rate of liming about $50 \%$ of the content of exchangeable $\mathrm{Mg}$ in the samples incubated without lime. The corresponding decrease in the exchangeable $\mathrm{K}$ was less regular, but in some samples the increase in the exchageable $\mathrm{Na}$ with liming was quite distinct.

There was an incubation experiment on nine loam and silt soils in which besides the effect of both liming and an application of $\mathrm{KCl}$, also the effect of 
alternate freezing and thawing on the exchangeable $\mathrm{Mg}$ could be studied. It was found that treatment with $0.5 \% \mathrm{CaCO}_{3}$ again distinctly decreased the amount of exchangeable $\mathrm{Mg}$ : the drop varied from 20 to $50 \%$ of $\mathrm{Mg}$ in the samples incubated for three months without liming. No difference in exchangeable $\mathrm{Mg}$ was detectable as a result of the presence of $\mathrm{KCl}$ in an amount of 2.5 $\mathrm{me} / 100 \mathrm{~g}$ of soil, neither did the alternate freezing or thawing bring about any net changes in $\mathrm{Mg}$.

\section{Discussion}

In all these experiments, heavy liming markedly decreased the amount of $\mathrm{Mg}$ which could be exchanged by various methods, and often also the content of exchangeable K was lowered. Since losses by leaching were excluded in the incubation experiments, fixation, or at least some kund of reduction in the exchangeability of these cations apparently occurred.

Liming has been found to increase fixation of K (KERÄNEN 1946, WIKLANDER 1954, KAILA 1965 etc.). This is most likely connected with release of aluminium hydroxide polymers from the interlayer position of clay minerals by the increase in soil $\mathrm{pH}$, but also other mechanisms may be involved.

Though fixation of $\mathrm{K}$ has been the subject of numerous papers, rather little is reported about the fixation of $\mathrm{Mg}$. Studies on the effect of liming on $\mathrm{Mg}$ usually treat the equilibrium between $\mathrm{Mg}$ in the soil solution and $\mathrm{Mg}$ sorbed as an exchangeable cation.

WikLANDER and Koutler-ANDERsson (1959) found that in a 30 years' field trial liming with $12000 \mathrm{~kg} / \mathrm{ha}$ of $\mathrm{CaCO}_{3}$ decreased the content of exchangeable $\mathrm{Mg}$ from $2.7 \mathrm{me} / 100 \mathrm{~g}$ in the unlimed plots to $2.2 \mathrm{me} / 100 \mathrm{~g}$. They supposed this to be connected with losses of $\mathrm{Mg}$ by a higher leaching rate from the limed plots. On the other hand, they reported that air-drying of the soil samples decreased the exchangeable $\mathrm{Mg}$ in the limed plots by about $8 \%$ of that in the undried samples from the surface layers down to the depth of $35 \mathrm{~cm}$; in the samples from the unlimed plots the effect of drying was detectable first in deeper layers. The authors refer to a previous work (MALQUORI and WIKLANDER 1950) which proved that both aluminium and iron silicates fixed $\mathrm{K}$ and particularly $\mathrm{Mg}$ in nonexchangeable form, probably as insoluble $\mathrm{K}$ - and $\mathrm{Mg}$ silicates. In addition to the formation of $\mathrm{Mg}$-silicates, $\mathrm{Mg}$ - $\mathrm{Al}$-silicates, or $\mathrm{Mg}$ Fe-silicates, also binding into the mineral structure is suggested as possible mechanism for this fixation brought about by drying of soil samples.

Also EAton et al. (1968) showed that $\mathrm{MgSiO}_{4}$ precipitates in soils at high pH. Hunsaker and Pratt (1970), on the other hand, demonstrated the formation of mixed $\mathrm{Mg}$-Al-hydroxides in soils when raised to alkaline $\mathrm{pH}$-levels. Doner (1967, ref. Hunsaker and Pratt 1970) confirmed the inclusion of $\mathrm{Mg}$ in $\mathrm{CaCO}_{3}$ as it precipitated. MCLEAN and CARBonell (1972) again, suggested that conversion of $\mathrm{Mg}$ to nonexchangeable forms as a result of liming of a silt soil to $\mathrm{pH} 6.8$ may have been primarily by chelation via organic components or by precipitation as oxalates, fatty acids or phosphates rather than by precipitation as silicates or aluminosilicates. 
It is difficult to see which of these mechanisms was responsible for the fixation of $\mathrm{Mg}$ in the soils of the present study. The samples were air-dried before analysing, and it probably intensified the retention of $\mathrm{Mg}$. In any case, the combined effect of incubation, liming and air-drying bound $\mathrm{Mg}$ as compounds or complexes which were not readily soluble in $0.5 \mathrm{~N} \mathrm{HCl}$, contrary to $\mathrm{K}$ fixed under the same conditions. Further studies are needed to ascertain the nature and importance of $\mathrm{Mg}$ fixation induced by liming.

It is of interest to note that in an experiment carried out by WIKLANDER and Koutler-Andersson (1963), the amount of $\mathrm{Mg}$ transferred from nonexchangeable to exchangeable form during one year's storage was rather low in soil samples saturated with Ca-ions as compared to samples saturated with $\mathrm{H}$-ions. Release of nonexchangeable $\mathrm{Na}$ tended to be slightly higher in samples saturated with $\mathrm{Ca}$-ions than in those saturated with $\mathrm{H}$-ions, but the contrary seemed to be true with changes in $\mathrm{K}$. The present results do not disagree with these data, if differences in the treatments are taken into account.

In a previous work (KAILA and KetTUNEN 1973), it was found that while some slight release of nonexchangeable $\mathrm{Mg}$ was detectable in most soils applied to exhaustive cultivation in greenhouse, the muddy clay soil which was the only sample treated with lime, did not show any net release of nonexchangeable $\mathrm{Mg}$. It is likely that one reason for the rather low amounts of plant-available $\mathrm{Mg}$ in the Finnish muddy clay soils is the effect of the fairly heavy liming which is usually needed for profitable cultivation of these acid soils.

\section{REFERENCES:}

Duncan, D. B. 1955. Multiple range and multiple F tests. Biometrics 11: 1-42.

Eaton, F. M., McLean, G. W., Bredell, G. S. \& Doner, H. E. 1968. Significance of silica in the loss of magnesium in irrigation waters. Soil Sci. 105: 260-280.

Hunsaker, V. E. \& Pratr, P. E. 1970. The formation of mixed magnesium-aluminum hydroxides in soil materials. Soil Sci. Soc. Amer. Proc. 34: 813-815.

KaIlA, A. 1965. Fixation of potassium by soil samples under various conditions. J. Scient. Agric. Soc. Finl. 37: 195-206.

- - \& Kettunen, H. 1973. Magnesium-supplying power of some Finnish mineral soils. J. Scient. Agric. Soc. Finl. 45: 319-324.

KerÄNEN, T. 1946. Kaliumista Suomen maalajeissa. Summary: On potassium in Finnish soils. Acta Agr. Fenn. 63.

Malquori, A \& WikLANDER, L. 1950. Influence of alternate wetting and drying on potassium and magnesium fixation and base exchange capacity of synthetic aluminium and iron silicates. IV Int. Cong. Soil Sci. Trans. I: 141-1.51.

Mclean, E. O. \& CARbonell, M. D. 1972. Calcium, magnesium, and potassium saturation ratios in two soils and their effects upon yields and nutrient contents of German millet and alfalfa. Soil Sci. Soc. Amer. Proc. 36: 927-930.

WikLander, L. 1954. Forms of potassium in the soil. Rep. Potassium Symposium 1954, Berne: $109-121$.

- - \& Koutler-Andersson, E. 1959. Kalkens markeffekt III. Grundförb. 12: 1-40.

- - \& Koutler-Andersson, E. 1963. Influence of exchangeable ions on release of mineralbound ions. Soil Sci. 95: 9-15. 


\title{
Kalkituksen vaikutus maan emäksisiin vaihtuviin kationeihin
}

\author{
Armi KaIla \\ Yliopiston maanviljelyskemian laitos, Viikki
}

Kalkituksen vaikutusta hiekkamaan, aitosaven ja liejusaven emäksisiin vaihtuviin kationeihin tutkittiin 9 kk:n muhituskokeessa laboratorion olosuhteissa. Lisäksi tarkasteltiin eräitten muitten muhitus- ja kenttäkokeitten analyysitietoja.

Todettiin, että $\mathrm{CaCO}_{3}$ annettuna määrinä, jotka nostivat maan reaktioltaan suunnilleen neutraaliksi, alensi kaikissa kokeissa merkittävästi vaihtuvan $\mathrm{Mg}$ :n pitoisuutta. Heikompikin kalkitus näytti estävän liejusaven vaihtumattoman $\mathrm{Mg}: \mathrm{n}$ nettomobilisoitumisen, jota oli havaittavissa, kun maata muhitettiin ilman kalkitusta. Useimmissa maissa oli havaittavissa myös K:n pidättymistä kalkituksen tuloksena, mutta vaihtuva $\mathrm{Na}$ yleensä lisääntyi kalkituksen myötä.

Kalkituksen aikaansaama $\mathrm{K}: \mathrm{n}$ ja $\mathrm{Mg}: \mathrm{n}$ pidättyminen oli mekanismiltaan erilaista: ainakin aitosavi- ja liejusavinäytteistä $0.5 \mathrm{n} \mathrm{HCl}$ uutti kalkituista ja muhitetuista maista merkittävästi văhemmän $\mathrm{Mg}$ kuin alkuperäisistä, mutta K:n kohdalta tulos oli päinvastainen.

Tulosten tarkastelussa käsiteltiin Mg:n pidätyksen mekanismia kirjallisuuden melko niukkojen olettamusten perusteella. Esitettiin, että mahdollisesti eräänä syynä liejusaviemme yleensä heikohkoon Mg-tilaan saattaa olla näiden maiden tavallisesti vaatima verraten voimakas kalkitus, joka voi johtaa Mg:n pidättymiseen vaihtumattomaksi. 